\title{
The past and present war: political cartoons and the memory of the First World War in Britain
}

This article examines the use of the First World War as an illustrative reference amongst

British political cartoonists as a means of perpetuating the memory of a conflict fought at the outset of the twentieth century. Through the application of a critical discourse analysis on examples of comic art within newspapers in Britain, this study will reveal how a distinct vision of the war is maintained for the purposes of social commentary and critique. This assessment will reveal how it is the image of the battlefields, trenches and suffering soldiers of the war that is recalled to ensure that it can be mobilised to address issues of contemporary concern. Therefore, this study will demonstrate how cartoonist and audiences return to 'the trenches' to make a past war appear present.

\section{Keywords}

Trenches, no man's land, battlefields, war, popular memory 


\section{The past and present war: political cartoons and the memory of the First World War in}

\section{Britain}

\section{Introduction}

The First World War possesses an evocative quality for contemporary British society. To speak of the trenches, no man's land, the Somme, Passchendaele, Gallipoli or Ypres is to almost automatically conjure images of a war-torn landscape, drenched in mud, ridden with craters, where soldiers suffered both the maelstrom of industrialised warfare and the incompetence and indifference of the military and political elite who commanded them. From the crowds gathered around the Cenotaph in London and local war memorial every Armistice Day on November 11, with the poppies sold by the British Legion for the benefit of all veterans of Britain's war but symbolising the dead of the First World War, to the sea of headstones and the name upon name on the monuments to 'the missing' on the memorial landscape of France and Flanders, this is a practice and performance of memory which is intimately tied to the visual. ${ }^{1}$ These images of the battlefields, of specifically the Western Front, are also reiterated within the ever-increasing number of television programmes, film and literature which seek to represent the conflict to present audiences. Indeed, the dominance of this particular way of seeing the war has led some scholars to critique this representation as collection of clichés that perpetuates a misguided or erroneous understanding of the industrialised conflict fought at the outset of the twentieth century. ${ }^{2}$ With the advent of the centenary of the outbreak of the war in August 2014, this critique of the 'popular memory' of the conflict sought to realign the image of the conflict from one of pity and trauma to one of success, victory and endeavour. This assessment regards the dominant image of the conflict to

\footnotetext{
${ }^{1}$ Ross Wilson, Cultural Heritage of the Great War in Britain (Farnham: Ashgate, 2013), 5.

${ }^{2}$ Brian Bond, The Unquiet Western Front (Cambridge: CUP, 2002).
} 
have been formed by the media representations of the war. However, through an assessment of political cartoons and comic art within British newspapers from the period of the conflict itself to the present that reference the battlefields, 'the trenches' and the soldiers, the function of these representations can be examined. Using the approach of critical discourse analysis, political cartoons and their place within wider society, rather than appearing to be the vapid, 'media-ted' consumption of images, can be regarded as an expression of and dialogue with power, place and identity. As a medium of communication, comic art highlights the function of this vision of the past; comic art renders this history present.

\section{Image and popular memory: Britain and the First World War}

The popular memory of the First World War in Britain has been the subject of increasing criticism from historians and right-wing politicians since the $1990 \mathrm{~s}^{3}$ This critique is derived from the assessment of the particular remembrance of the conflict being a 'myth', constructed by the poetry, memoirs and novels of a small number of disillusioned officers during the war and in its aftermath which have then been taken as truthful accounts of the reality of the four years of war. ${ }^{4}$ Individuals such as Wilfred Owen (1893-1918), Robert Graves (1895-1985) and Siegfried Sassoon (1886-1967) have been regarded as the origin point of the Western Front as a 'literary topos'. In their work, a specific description of the battlefields of France and Flanders and those who served in the trenches is observed to have emerged which has structured remembrance. Owen, the tragic soldier-poet of the war wrote in his letters of the broken landscape:

\footnotetext{
${ }^{3}$ Gary Sheffield, Forgotten Victory (London: Headline, 2001).

${ }^{4}$ Dan Todman, The Great War: Myth and Memory (London: Hambledon, 2005).
} 
It is like the eternal place of gnashing of teeth; the Slough of Despond could be contained in one of its crater-holes; the fires of Sodom and Gomorrah could not light a candle to it...it is pock-marked like a body of foulest disease and its odour is the breath of cancer...5

Similarly, Sassoon described the shattered bodies and minds of those soldiers who inhabited the battlefields in his well-known work 'Suicide in the Trenches':

In winter trenches, cowed and glum,

With crumps and lice and lack of rum,

He put a bullet through his brain.

No one spoke of him again. ${ }^{6}$

Graves also recounted the suffering that he witnessed along the Western Front which was caused by the effects of industrialised war but also the apparent insensitivity and uncaring response towards the ordinary soldier from the higher echelons of the British Army:

...when a staff-officer came by in a Rolls-Royce and cursed us for bad marchdiscipline, I felt like throwing something at him. Trench soldiers hate the staff and the staff know it. The principal disagreement seems to be about the extent to which trench conditions should modify discipline. ${ }^{7}$

In these accounts, all largely published after the cessation of hostilities during the 1920s and 1930s, when disillusioned accounts of wartime experience found a receptive audience during

\footnotetext{
${ }^{5}$ Wilfred Owen, The Collected Poems of Wilfred Owen (London: Chatto and Windus, 1964), 160.

${ }^{6}$ Siegfried Sassoon, Counter-attack, and other poems (London: Heinemann, 1918), 31.

${ }^{7}$ Robert Graves, Goodbye to all that (London: Jonathan Cape, 1929), 107.
} 
the turbulent interwar years, the battlefields takes upon the image of suffering and torment for the soldiers and evoke a response of unquestioning pity. ${ }^{8}$ It is this perception of the battlefields which has been subsequently been reiterated across a variety of media over the proceeding decades. From the scenes of incompetent officers depicted in the renowned theatre production and later film of Oh! What a Lovely War, the dark comedy of Blackadder Goes Forth and the novels from the 1990s of Birdsong and Regeneration, the Western Front is rendered in the same way. ${ }^{9}$ Such is the dominance of this particular vision of the battlefields that some scholars have regarded it as a cliché of 'rats, gas, mud and blood', constructed and maintained through mass media. ${ }^{10}$ Indeed, some historians have highlighted the existence of 'two' Western Fronts, one which exists within cultural representations and the other which has its basis in historical fact. ${ }^{11}$ The critique of the popular memory of the war is that it bears no relation to reality; historians have demonstrated the high morale amongst troops, the tactical development amongst the high command and the political will which saw eventual victory in the field. ${ }^{12}$ The reason for the departure from history and the prevalence of the popular memory of the war has been frequently stated as the result of the passive consumption of media representations. ${ }^{13}$

However, in the desire to stress the nature of the 'invented tradition' of this popular memory, scholars have frequently disregarded or derided the significance that this memory holds within society and the mediums through which these ideas are communicated. ${ }^{14}$ In Britain, the popular memory serves as an important part in the formation of identity; political,

\footnotetext{
${ }^{8}$ Samuel Hynes, A War Imagined: The First World War and English Culture (London: Bodley Head, 1990$), 12$.

${ }^{9}$ Theatre Workshop, Oh! What a Lovely War (London: Methuen, 1965); Richard Attenborough (Dir.), Oh! What a Lovely War (London: Paramount); Richard Boden (Dir.) Blackadder Goes Forth (London: BBC, 1989); Sebastian Faulks, Birdsong (London: Hutchinson, 1993); Pat Barker, Regeneration (London: Viking, 1991). ${ }^{10}$ Gordon Corrigan, Mud, Blood and Poppycock (London: Cassell, 2003).

${ }^{11}$ Stephen Badsey, Blackadder Goes Forth and the "Two Western Fronts" Debate', The Historian, Television and Television History, ed. Graham Roberts and Paul Taylor (Luton: University of Luton Press, 2001, 113-125.

${ }^{12}$ Stephen Heathorn, Haig and Kitchener in Twentieth-Century Britain (Farnham: Ashgate, 2013).

${ }^{13}$ David Williams, Media, Memory, and the First World War (Montreal and Kingston: McGill-Queen's University Press, 2009).

${ }^{14}$ After Raphael Samuel, Theatres of Memory (London: Verso, 1994), 7.
} 
national and moral. ${ }^{15}$ The image of the suffering soldier in the trenches has been used to mobilise political identities, as left-wing elements have drawn upon the notion of incompetent upper-class officers sending wave after wave of working-class men to their deaths in a pointless attack to highlight abuses of power and the neglect of society by authorities. Conversely, right-wing elements in Britain extol the virtues of the generation that endured the horrors of industrialised war stoically and heroically. This vision of the conflict is also of increasing significance for regional and national identity within Britain as Scottish, Welsh and regional English identities have all used the conflict to express concepts of place and belonging. The conflict is also used to advocate a nostalgic sense of tradition, as evocations of 'Blighty', the soldiers' vernacular term for Britain, appears to emphasise the stoicism and dedication of the troops as part of a wider British national identity. Finally, the conflict also possesses relevance for a moral and ethical stance as the image of brutalised troops experiencing the horrors of industrialised war exercises a sense of injustice and activism. Therefore, understanding the effect of the war's remembrance within society reveals how the conflict is drawn upon for contemporary agendas. Whilst the popular memory has been the object of debate and a target for revision, commentators have overlooked the function and utility of this remembrance.

This purpose is especially significant in the consideration of the persistence of this popular memory. Despite the attempts of scholars to challenge the widely held perceptions of the war in Britain, it is the image of 'mud, blood, rats and gas' that still dominates. Remembering the battlefields of the First World War as a devastated war landscape formed through the effects of industrialised conflict where individuals suffered unimaginable torments caused by artillery, gas, machine guns and the policies of the military and political elite has endured. Therefore, rather than seeking to challenge the well-held popular memory,

\footnotetext{
${ }^{15}$ See Cultural Heritage of the Great War, 12.
} 
the issue of examination should be why there is a focus on the trauma of the war through a variety of different media. In this regard the cultural representations are vital components in understanding how this popular memory works and its effects. ${ }^{16}$ Whilst novels, film, television programmes and other media have been assessed as the source of memory, this assessment neglects a close reading of the material for the values, identities and perspectives it reflects. ${ }^{17}$ This dismisses the potential study of cultural forms for how they structure remembrance. An analysis of the way in which comic art and political cartoons have been used as frames through which the war has been remembered provides a new agenda in this field. ${ }^{18}$ Examining the uses of remembrance through these representations of conflict demonstrates how certain images of the war are elevated above others because they are presumed to be better reflections of the 'truth' of the war. This truth is not born out of historical accuracy and close statistical analysis; rather it is formed through how individuals, groups and communities regard the conflict and its place and value within society. Therefore, the appearance of such references indicates a far more complex use of the image of the First World War within British popular culture. Politics, power, place and identity are all mobilised with the references made in political cartoons to the war of 1914-1918 and these sentiments have been drawn upon to create frames of reference to understand present concerns. ${ }^{19}$

These frames of reference, represented by the work of cartoonists, can be regarded as the product of the social and political relations which can indicate the values and ideals of wider society. ${ }^{20}$ These relations can be identified through the application of a critical discourse analysis (CDA); an approach that has been developed to identify the structure of

\footnotetext{
${ }^{16}$ See James Wertsch, Voices of Collective Remembering (Cambridge: CUP, 2002), 12-15.

${ }^{17}$ Voices of Collective Remembering, 17.

${ }^{18}$ See Jane Chapman, Never again! World War 1 in cartoon and comic art (Exhibition at the Cartoon Museum, London), http://www.cartoonmuseum.org/exhibitions/current-exhibitions.

${ }^{19}$ Teun van Dijk, News as discourse (Hillsdale, NJ: Lawrence Erlbaum Associates, 1987).

${ }^{20}$ Erving Goffman, Frame Analysis (New York: Harper and Row, 1974), 5.
} 
discourse within the political, media and public sphere. ${ }^{21}$ Essentially, CDA can expose how society is organised through the way in which text and images are employed. CDA, as a methodology, analyses the discourses used within institutions and groups, focusing on the 'work' that language does, how it unifies, divides and identifies peoples and values. CDA provides a means to understand how representation through a variety of media, filtered through various systems of power can structure experience. ${ }^{22}$ This approach is based upon the identification of the function and value of communication. ${ }^{23}$ Rather than assuming that discourse is merely a reflection of power, CDA recognises that the application of discourse is purposeful and possesses social and political effect. Therefore, the analysis of discourse, whether visual or textual, forms a means of identifying values and perceptions within a group, community or society. It also demonstrates how the interaction that occurs between representation and consumption is not merely a simplistic, linear model. Rather, it is a recursive relationship, which reflects how discourses serve as a means of mobilising identity and ideals. With the agenda defined by CDA, the discourses used within any media do not represent a prescriptive demand upon society to view an issue in a particular manner but a means through which society negotiates and defines itself. Therefore, the application of CDA to political cartoons presents a particularly valuable subject of study. These illustrations have traditionally occupied a unique place within cultural life; they are frequently both the site of authority but also political dissidence. Despite the relevance of this methodology with political cartoons, the use of CDA to examine 'comic art' more generally has been largely

\footnotetext{
${ }^{21}$ Norman Fairclough, Critical discourse analysis: The critical study of language (London: Longman, 1995); Norman Fairclough, Language and Power (London: Longman, 2001).

${ }^{22}$ Language and Power, 15.

${ }^{23}$ Ibid, 26.
} 
restricted to the study of the graphic novel. ${ }^{24}$ This follows the development of a sophisticated assessment of the graphic novel as a rigorous, academic pursuit. ${ }^{25}$

Building upon this development within graphic novel studies, political cartoons can be examined as significant frames through which to view historical events and current concerns. ${ }^{26} \mathrm{CDA}$ can be applied to this material to examine the way in which it functions within society, not solely as an instructional framework or as a reflection of wider issues but as the product of a set of complex social and political relations. ${ }^{27}$ To clarify the approach taken with CDA, Fairclough and Wodak highlighted a series of fundamental tenets to describe and guide the application of the technique:

- CDA addresses social problems

- Power relations are discursive

- Discourse constitutes society and culture

- Discourse does ideological work

- Discourse is historical

- The link between text and society is mediated and interpreted

- Discourse analysis is explanatory

- Discourse is a form of social action ${ }^{28}$

\footnotetext{
${ }^{24}$ Frank Bramlett, 'Introduction', Linguistics and the Study of Comics, ed. by Frank Bramlett (Houndmills: Palgrave Macmillan, 2012), pp.1-12; Hannah Miodrag, 2013. Comics and Language: Reimagining Critical Discourse on the Form (Jackson: UP of Mississippi, 2013), 5.

${ }^{25}$ Jan Baetens and Hugo Frey, The Graphic Novel: An Introduction (Cambridge: CUP, 2014).

${ }^{26}$ Josh Greenberg, 'Framing and Temporality in Political Cartoons: A Critical Analysis of Visual News Discourse', Canadian Review of Sociology 39(2) (2002), 181-198; Jamila Hakam, "The "cartoons controversy": a critical discourse analysis of English-language Arab newspaper discourse', Discourse \& Society 20(1) (2009), 33-57.

${ }^{27}$ Mary M. Talbot, Karen Atkinson and David Atkinson, Language and Power in the Modern World (Edinburgh: Edinburgh University Press, 2003); Mary Talbot, Fictions at Work: Language and Social Practice in Fiction (London: Routledge, 2014).

${ }^{28}$ Norman Fairclough and Ruth Wodak, 'Critical Discourse Analysis', Discourse as Social Interaction, ed. Teun van Dijk (London: Sage, 1997), pp.258-284.
} 
In this approach, CDA examines discourse, verbal, textual or visual, as emerging within specific socio-political contexts that define a particular historical era. Therefore, by examining how a community represents issues, the language used, the imagery that is drawn or the subtext that is present, an insight into how that community assesses the significance of an event or concern can be stated. At the centre of these debates is the operation of power within society through discourse; the ability to control and organise discourse evidences a high degree of authority but it also ensures that discourse itself becomes a site of resistance to that authority. Through the framing, position and identification within discourses the operation of power can be evidenced and challenged. ${ }^{29}$ Indeed, by defining phrases, allusions, references and motifs, CDA demonstrates the latent, hegemonic structures of control within society as well as revealing the dissonant voices that emerge through that same mode of representation. Drawing upon this approach, political cartoons can be used to demonstrate how they have functioned within British society as they reference the conflict of 1914-1918. The analysis of this material will focus on the historical development of the political cartoon during the war itself and then into the post-war era. ${ }^{30}$ This will establish how the conflict becomes reused for wider agendas and becomes part of a wider socio-cultural discourse. The analysis will then examine how political cartoons have mobilised aspects of the war in the recent era between 1998 and 2013 to examine concerns regarding military action but also far broader topics that are connected to issues of leadership, competence and responsibility. Three elements will be focused upon throughout this assessment; the desolated battlefields, the trenches and the figure of the soldier. These aspects of political cartoons in Britain that reference the war are highly noticeable for their continued presence within this media. The reuse of such imagery, however, is not the product of a clichéd imagining of the conflict, as battlefields, the trenches and the figure of the soldier are used to comment upon issues beyond the confines of the war

\footnotetext{
${ }^{29}$ Language and Power, 26.

${ }^{30}$ Mark Bryant, World War I in cartoons (London: Grub Street, 2006).
} 
of 1914-1918. This evidence indicates the way in which the popular memory of the conflict is not the product of media representation but demonstrates how the conflict is used to express a variety of concerns and agendas.

\section{Comic art and the First World War}

Comic art and specifically political cartoons in Britain are uniquely positioned as a subject matter to examine how the remembrance of the war is constructed through a particular discourse that serves those who honour its memory. From the outset of the war in August 1914, the format has had a strong association with the British Army during the First World War and has frequently served as a vehicle for political and social expression. ${ }^{31}$ During the war, Bruce Bairnsfather's (1887-1959) humorous depiction of the dishevelled figure of 'Old Bill' featured in his regular feature for The Bystander, 'Fragments from France', appeared to evoke the stoic characteristics of the everyday 'Tommy' in the trenches. ${ }^{32}$ Bairnsfather's wellknown illustration of a blasted war landscape with 'Old Bill' and his comrade enduring an artillery barrage in a crater with the line, 'Well, if you knows of a better 'ole, go to it' summarised the phlegmatic, darkly comic humour which would enable the troops to meet the challenge of the war and achieve victory. These images were highly popular and served to instil a sense of endurance for both soldiers at the front and their families and friends on the home front. ${ }^{33}$ Similarly, the work of cartoonists and artists such as Heath Robinson (18721944), Sidney Strube (1891-1956) and Donald Gill (1875-1962), encouraged fortitude amongst the populace with comic depictions of excessively complicated machinery used in

\footnotetext{
${ }^{31}$ Steve Baker, 'Describing Images of the National Self: Popular Accounts of the Construction of Pictorial Identity in the First World War Poster', Oxford Art Journal (1990) 13(2), 24-30; Wolfgang K. Hünig, British and German Cartoons as weapons in World War I. (Frankfurt am Main: Lang, 2002); Pearl James (ed.), Picture This World War I Posters and Visual Culture (Lincoln: U. Of Nebraska Press, 2009).

${ }^{32}$ Bruce Bairnsfather, Bullets \& Billets (London: Grant Richards, 1916).

${ }^{33}$ Bruce Bairnsfather, Fragments from France (London: The Bystander, 1916), 13.
} 
the war effort alongside illustrations of an incompetent, militaristic enemy. ${ }^{34}$ Alfred Leete (1882-1933) also contributed to the war effort with his commissioned and now iconic depiction of Lord Kitchener, Secretary of State for War, appealing to the patriotism of the public with his finger pointed outwards and the slogan 'Britons: Lord Kitchener Wants You. Join Your Country's Army! God save the King'. ${ }^{35}$ Comic art and graphic design was thereby mobilised for the war effort to encourage participation and commitment amongst both civilians and soldiers. The trench newspapers, published behind the lines by officers, circulated amongst the troops and tolerated by the General Staff also featured illustrations which parodied both German and British war policies. ${ }^{36}$ The celebrated Wipers Times frequently utilised comic art to highlight the absurdity of war but as a mode of endurance rather than dissent. ${ }^{37}$ During wartime, comic art, whilst capable of expressing the dangers and privations of the conflict, ultimately was a tool which was accessed by individuals and the authorities for ensuring support and commitment to the war effort.

By the 1920s and 1930s, comic art began to draw upon the image of the First World War for alternative purposes, utilising the conflict as a means to express ideas of common experience, endurance and a shared sense of suffering. Cartoonists such as David Low (1891$1963)$ and W.K. Haselden (1872-1953) drew upon visual or verbal references to 'the trenches', 'the war' or the 'the battlefields' as a means of social critique. In their work published in national newspapers, comic art provided a frame through which current concerns were referenced in relation to the past. In Low's work, the war serves as a means to hold society to account. This can be observed from the very outset of the 1920s. In his work, published in The Star in July 1921, the conditions of 'the trenches' are used as a point of

\footnotetext{
${ }^{34}$ Heath Robinson, Some "Frightful” War Pictures (London: Duckworth, 1915); Heath Robinson, Hunlikely! (London: Duckworth, 1916); Heath Robinson, The Saintly Hun: a book of German virtues (London: Duckworth, 1917); William Haselden, The Sad Adventures of Big and Little Willie (London: Chatto \& Windus).

${ }^{35}$ London Opinion, September 51914.

${ }^{36}$ Graham Seal, The Soldiers' Press: Trench Journals in the First World War (Houndmills: Palgrave Macmillan, 2013).

${ }^{37}$ The Wipers Times, July 31916.
} 
contrast with the dire conditions of social housing provided by the government's 'Homes for Heroes' initiative which was designed to remove veterans and their families from the slums. ${ }^{38}$ The same point is made a year later by Low also in The Star, as the cartoonist further criticises the housing policy in relation to the war as he pictures a hard-headed economist stating, 'Let every hero dig his own home. They will love the idea. So reminiscent of the happy days of the war - (and so cheap)' ${ }^{39}$ Intriguingly, the image of the First World War also served as a means to depict the conflict of 1939-1945; trenches, shell-blasted landscapes and the stoicism of soldiers under fire enabled cartoonists to reiterate the same concepts of endurance that were present in depictions of the war of 1914-1918. For example, the cartoonist Ronald Giles (1916-1995) uses the illustration of the Western Front in a cartoon published in the Daily Express in April 1944, as three British soldiers sleep beneath a canopy of exploding shells, with one soldier rebuking his comrades' discussion of post-war life to focus on the present with the comment, 'Suppose you two quit talking about prefabricated houses and go to sleep? ${ }^{40}$ This evocation of the imagery of 1914-1918 to understand the Second World War is present right from the outset of the conflict. E.H. Shepard (1879-1976) in an edition of Punch dated October 1939 uses the trenches of the Western Front to comment upon the machinations of Nazi Germany. ${ }^{41}$ Throughout the interwar period and into the second global conflagration that engulfed Europe, comic artists in Britain repeatedly referred to the war as a means of expressing wider ideas. The conflict of 1914-1918, the trenches, no man's land and the battlefields symbols used to illustrate contemporary concerns. Far from possessing an innate meaning, the First World War provides a mode of expressing a range of issues from pride and endurance to analysis and censure.

\footnotetext{
${ }^{38}$ The Star, July 181921.

${ }^{39}$ The Star, April 251922.

${ }^{40}$ Daily Express, 2 April 1944.

${ }^{41}$ Punch, 15 October 1939.
} 
In the aftermath of the Second World War, the conflict of 1914-1918 continued to perform this function within comic art in Britain. Indeed, 'the trenches' after 1945 became a consistent visual element within depictions to highlight concerns and agendas within contemporary Britain. In this usage, the trauma of the conflict, the devastation and loss caused by the war serves as a lens through which current problems are expressed and addressed. It is 'the trenches' that are referred to in discussions of the crises and concerns that beset Britain during this era. This is demonstrated with the work of Victor Weisz (1913-1966) in the Daily Mirror in January 1956 as he mocked the Home Office's official manual regarding safety in event of the nuclear war by illustrating a war landscape left cratered and broken with the less than reassuring suggestion that citizens could find shelter in home-made trenches. ${ }^{42}$ Similarly, Leslie Illingworth (1902-1979) in the Daily Mail in November 1956, used the image of politicians lined in the trenches with Prime Minister Antony Eden going 'over the top' to face an unknown fate as he assessed the ambiguity of Britain's war with Egypt during the Suez Crisis (1956). ${ }^{43}$ The malleability of the battlefield scenes of the First World War and its symbolic significance enable political cartoonists to frame a variety of issues through this context. Norman Mansbridge (1911-1993) in Punch during July 1963 portrays the lack of dialogue between China, Russia and the United States as a dead-locked Western Front with each party entrenched. ${ }^{44}$ Whilst Victor Weisz in the Evening Standard of October 1963 depicts the Labour Party political conference as an immobile scene in the trenches with wistful politicians reminiscing about a 'home front' back in the seat of power, Number 10 Downing Street. ${ }^{45}$ Applied to concerns beyond the events of 1914-1918, the battlefield landscape and the trenches becomes a means of mobilising opinion.

\footnotetext{
${ }^{42}$ Daily Mirror, 23 January 1956.

${ }^{43}$ Daily Mail, 1 November 1956.

${ }^{44}$ Punch, 8 July 1956.

${ }^{45}$ Evening Standard, 1 October 1963.
} 
Frequently, from the 1960s onwards, political cartoons refer to the conflict as a means of expressing dissent towards authority, highlighting abuses of power, lapses in responsibility and attempting to hold individuals and institutions to account. This can be observed in the evocation of the war on the Western Front in the critical appraisal of the operation of the United States in Vietnam (1955-1975). Soldiers of the U.S. Army were placed in the 'trenches', 'shell-holes' and 'no man's land' of France and Flanders as the military and political policies of their nation were criticised. Raymond Jackson (1927-1997) as cartoonist for the Evening Standard newspaper in the late 1960s, repeatedly drew upon the imagery of the First World War to highlight issues of incompetency, waste and the failings of the operations of the United States in Vietnam. ${ }^{46}$ Within a domestic context, the Western Front was also used to illustrate the buffoonery of officialdom. John Jensen, in the Sunday Telegraph of September 1968, depicts the Labour Prime Minister Harold Wilson (1916-1995) and the Labour Deputy Leader George Brown (1914-1985) in the trenches, surrounded by exploding ordinances named after the crises that beset the administration, but unaware of the wider environment. ${ }^{47}$ The same theme of an absence of competent leadership can be located in Michael Cummings (1919-1997) depiction in February 1971 in the Daily Express of the standoff between the Conservative Government led by Prime Minister Edward Heath (19162005) and members of the Trades Union Congress (TUC) was set on the Western Front. In this image, members of the TUC ruling council send a forlorn looking private soldier, representing the Post Office workers, 'over the top' to meet the enormous artillery of the establishment. ${ }^{48}$ Similarly, Nicholas Garland, drawing for the Daily Telegraph in January 1972, illustrates the hopelessness of the TUC position as they prepare to launch another offensive to go 'over the top' amongst the detritus of previous failed endeavours. ${ }^{49}$

\footnotetext{
${ }^{46}$ Evening Standard, 9 November 1965; Evening Standard, 2 February 1968.

${ }^{47}$ Sunday Telegraph, 29 September 1968.

${ }^{48}$ Daily Express, 22 February 1971.

${ }^{49}$ Daily Telegraph, 10 January 1972.
} 
Conversely, Raymond Jackson in his work from February 1973 in the Evening Standard depicted the Conservative Government of Edward Heath as officers in the trenches, blithely unaware of the dangers that would be faced with the massed ranks of the unions across no man's land.$^{50}$ In this manner, the site of battlefields has become invested with symbolic meaning, emphasising waste, destruction and incompetence.

This emblematic nature of the battlefields does not appear to be owned by one political hue or another during this era as 'the trenches' provide a visual locale where hypocrisy and ineptitude can be signalled. In his cartoon of June 1974 in the Daily Mail, John Musgrave-Wood (1915-1999) portrayed the Prime Minister Harold Wilson and Secretary of State for Industry Tony Benn as two generals sat in a shell-hole amidst a blasted war landscape oblivious to the tumult of war around them as they attempted to mount an offensive. ${ }^{51}$ As a medium of expressing social, cultural and industrial discontent, the Western Front serves as the example par excellence for political cartoonists. For example, Leslie Gibbard (1945-2010), in the Guardian newspaper of December 1981, returned to 'the trenches' to highlight the difficulties faced by the Labour Party leadership under Michael Foot (1913-2010), which was under increasing attack from centre-right forces amongst its own ranks and competing policies from the recently founded Social Democratic Party. Up to his knees in mud, Foot oversees the digging of trenches as one of the unit states, 'Trenches dug just where you said...Let's hope it's a short campaign!'52 Gibbard thereby alludes to the long, drawn-out nature of the war of 1914-1918 to illustrate the damaging and prolonged route ahead for the Labour Party. Michael Cummings uses the same picture of a war of attrition in the Daily Express in November 1984 to lampoon the bitter confrontation between the Conservative Government led by Margaret Thatcher (1925-2013) and the National Union of Miners headed by Arthur Scargill. A shell-cratered no man's land divides the ranks of striking

\footnotetext{
${ }^{50}$ Evening Standard, February 121973.

${ }^{51}$ Daily Mail, 17 June 1974.

${ }^{52}$ The Guardian, 8 Dec 1981.
} 
coalminers and a line of policemen as the possibilities of a 'Christmas Truce', mirroring the temporary ceasefire of 1914, is dismissed with the comments made by one of the officers:

Mind you, when I heard the Coal Board say "The war would be over by Christmas" I knew we' $d$ be in the trenches for another four years... ${ }^{53}$

By the 1990s, the Western Front had become a regular scene on which to place current politicians or public figures to highlight failings, difficulties or futility. Nicholas Garland, providing a commentary in February 1992 in the Daily Telegraph of the outset of the general election campaign, portrayed the Labour opposition and Conservative Government as occupying opposing trenches, trading childish insults across no man's land, thereby lamenting the stagnating political system within Britain. ${ }^{54}$ The battlefields of the First World War possess this symbolism within political cartoons in Britain because of their ability to convey such powerful messages regarding power within society. Illustrators and artists return to the subject matter to frame current concerns not because they are vapidly accepting a misinterpretation of history or due to their reiteration of clichés. Nor do viewers of these materials passively accept the images of the mud-strewn, cratered, dangerous and ill-judged arena of the Western Front as a 'truth'. Rather, the battlefields and war landscape of 19141918 serves as a frame of reference through which both artists and audiences comprehend current concerns. The failure of critics of the popular memory of the war in Britain to consider the conflict as nothing more than 'mud, blood, rats and gas' formed through media representations of the battlefields obscures the significant way in which these images are used to structure comprehension of the present through reference to the past.

\footnotetext{
${ }^{53}$ Daily Express, 30 November 1984

${ }^{54}$ Daily Telegraph, 28 February 1992.
} 


\section{The past war made present}

The place of the First World War within political cartoons since the 1990s has taken on an increasing significance as it is used to convey both incompetency and ineffectual leadership but has also been utilised as a means by which a damning indictment of official policies can be communicated. Whilst the battlefield landscape is still a feature of this work, it is the figure of the soldier, suffering and enduring life in the trenches which becomes increasingly prominent in this regard. This shift has been noted by commentators as representing an alternative remembrance, one which focuses on victimhood and the brutality of the war, thereby sentimentalising those who experienced the conflict. ${ }^{55}$ Indeed, such was the outpouring of grief and commemoration expressed across a variety of media during the commemoration of the eightieth anniversary of the Armistice in 1998 that some scholars were moved to remind the wider public that the war was actually over ${ }^{56}$ However, such a perception misunderstands the function of the media as a frame through which concerns are expressed about the present and presumes such representations to serve merely as a medium of passive nostalgia. ${ }^{57}$ The figure of the tormented soldier, thereby, acts as a call to account for contemporary society. Such an expression can be located in the cartoonist Steve Bell's work for the Guardian newspaper during November 1998. In this image, an original photograph of a battle-weary soldier resting in the trenches is used as a means to juxtapose this anguish with a representation of remembrance activities conducted in the present by politicians which serves to forget such pain. The image was accompanied with the text:

\footnotetext{
55 The Unquiet Western Front, 12.

${ }^{56}$ Stéphane Audoin-Rouzeau and Annette Becker, 14-18: Understanding the Great War (Hill and Wang: New York, 2002), 5.

${ }^{57}$ Raymond Williams, Culture (London: Fontana), 22.
} 
Oh lucky man, oh soldier, how dignified thou art! How meaningful they suffering, how great thy English heart! How tawdry this old peace is, how compromised its fruits! I envy thee thy lot in life - shell shock! Never shell suits!! ${ }^{58}$

The same theme is continued in the cartoonist Tom Johnston's work for the Daily Mirror also in November 1998 which illustrates a statue of an ordinary soldier, equipped to face the weather and the enemy, looking mournfully downwards as in the backdrop a war-ravaged landscape can be observed. The pedestal on which the statue is mounted reveals that the soldier commemorates the artist's grandfather who died during the Battle of the Somme (1916). ${ }^{59}$ The effect of this framing of the conflict of 1914-1918 is to ensure that the past is made present for contemporary agendas. This mode of focusing on suffering was a particular feature of the cartoons that assessed the British Government's policy during the 'War on Terror' during operations in Afghanistan (2001-2014) and Iraq (2003-2009). The First World War was employed as a framing device in the work of cartoonists to critique the loss of life, the seemingly endless nature of the conflicts and the incompetence of officials that pursued military action. For example, Peter Brookes, in The Times of July 2006, contrasts the image of dead soldiers scattered across the battlefields of the Somme of 1916 with the same image of corpses across the warzone of Helmand Province, Afghanistan in 2006. ${ }^{60}$ The trauma of the soldiers of the conflict from the First World War is used to assess the failings of the contemporary military and political classes to protect the lives lost in the nation's current military engagements. This was demonstrated in Martin Rowson's response to the death of the last veteran of the First World War, Harry Patch in the Guardian newspaper in July 2009. This places the coffin of Harry Patch being venerated by the Prime Minister Gordon Brown

\footnotetext{
${ }^{58}$ The Guardian, 11 November 1998.

${ }^{59}$ Daily Mirror, 12 November 1998.

${ }^{60}$ The Times, 4 July 2006.
} 
who has his back turned from the piles of the dead from the British Army's latest conflicts. ${ }^{61}$ Connecting past and present wars enables these cartoons to serve as a framework for society, not as a passive acceptance of memory and myth but as an active engagement in remembrance.

This is also demonstrated in the way in which the soldiers of the First World War are used within political cartoons to assess the current state of society. The figure of the 'Tommy' in 'the trenches' is so invested with pity, mourning and honour that its utilisation by cartoonists serves as a lesson in civics for contemporary audiences in Britain. Peter Brookes, responding in The Times in September 2011, to the revelations of prisoner abuse by British soldiers in Iraq during the early part of the conflict, compared 'going over the top' in 1914 with a sepia-tinged soldier emerging out of the trenches into the maelstrom with 'going over the top' in 2003, with a British soldier assaulting a hooded and restrained Iraqi detainee. ${ }^{62}$ Brookes continues this theme with his work in The Times in November 2013 after the successful prosecution of a Royal Marine for the unlawful killing of a prisoner in Afghanistan. Brooke manipulates the image of the Cenotaph in Whitehall, built in 1919 to honour the dead of the First World War, upon which has been carved 'The Geneva Convention' with the title of the piece 'Lest We Forget' ${ }^{63}$ The comparison between past and present finds contemporary society to be failing to achieve the heroism and sacrifice of their forebears. Such assessments can also be observed in Martin Rowson's work in The Guardian in July 2006 where the memorialised name upon name of the dead of the Battle of the Somme serve as the backdrop for a beer-swilling, smoking, shirtless and weeping England football fan as a sign for the 'War on Terror Iraq and Afghanistan Annex' is displayed in the foreground. ${ }^{64}$ The narrow, nationalistic commemoration of the dead of Britain's recent

\footnotetext{
${ }^{61}$ The Guardian, 27 July 2009.

${ }^{62}$ The Times, 9 September 2011.

${ }^{63}$ The Times, 11 November 2013.

${ }^{64}$ The Guardian, 3 July 2006.
} 
military operations is thereby positioned against the supposedly stately and sober remembrance of the dead of the First World War. In this manner, for a variety of agendas, the figure of the suffering soldier of the war of 1914-1918 can be used to highlight deficiencies in the present. The cartoonist Dave Brown, reflecting upon the preparations for the centenary of the war in The Independent newspaper in October 2012, drew upon the trauma experienced by the soldiers of the conflict with the effect of the austerity measures in Britain undertaken in the wake of the financial crisis of 2008. In an adaptation of a photograph taken of the battlefields on the Western Front with soldiers locked into a muddy, troglodyte existence, the cartoon's caption reads:

Bogged down in a hopelessly entrenched position, waging a futile war that wastes countless lives...but enough of the economy, how do we commemorate WWI ${ }^{65}$

The scene of slaughter from France and Flanders provides a means of indicting current politicians for their creation of another 'lost generation' in twenty-first century Britain. The cartoonist Steve Bell, illustrating for The Guardian in January 2013, also drew upon a wartime photograph of soldiers going up the line into no man's land. Titling his work 'Over the Top', Bell illustrates the Conservative Chancellor of Exchequer, George Osborne firing upon the soldiers with a machine-gun fed with unemployment forms. ${ }^{66}$ The damage wrought on the bodies of British soldiers fighting on the Western Font during the First World War forms a means of representing the folly of conflict and the danger of poor leadership. In response to discussions of military attacks on Syria in August 2013, Patrick Blower, in the Daily Telegraph, reused the famous wartime painting Gassed by John Singer Sargent (18561925). In the original, soldiers who are blinded by the effects of chlorine gas lead each other

\footnotetext{
${ }^{65}$ The Independent, 12 October 2012.

${ }^{66}$ The Guardian, 23 January 2013.
} 
blindly through a sea of bodies also afflicted by injury. In Blower's work, the blinded figures are international politicians, tragically leading each other towards another damaging confrontation. ${ }^{67}$ Therefore, the First World War appears within British political cartoons as a dire indication of what might happen, framing the present in the context of the past as a 'warning from history', employed to demonstrate the costs of conflict upon individuals, communities and wider society.

The place of the First World War as a lesson for current generations is a well established discourse within political cartoons. It serves as a means to caution politicians about their actions and criticise abuses of war. Cartoonists, such as Steve Bell, in his work for The Guardian newspaper, use this mode of representation repeatedly in their work. For example, Bell returns to 'the trenches' in April 1999 to examine the British Government's response to the NATO bombing campaign in Serbia that had attacked civilian targets. Depicting the government's Communications Chief, Alastair Campbell, leading assorted journalists of the nation's newspapers 'over the top' of the trenches into no man's land by declaring the mission to be 'humanitarian', the sense of waste, futility and incompetence is made clear. ${ }^{68}$ Peter Brooke, drawing for The Times in November 1998 makes the same allusion in the context of Britain's joint statement with the United States that no further negotiations would be made with Iraqi President Saddam Hussein (1937-2006). In Brooke's cartoon, the figure of Death links the field of headstones from the Western Front to fighter jets flying over the minarets of Baghdad. ${ }^{69}$ A similar use of the conflict is made by Nicholas Garland in his February 2008 assessment of the war in Afghanistan in the Daily Telegraph. Responding to the news that there would be a record poppy harvest within Helmand Province, Garland links the headstones of the First World War, wreathed in poppy garlands to lines of Taliban fighters armed with weapons bought with the proceeds of the opium trade. In this

\footnotetext{
${ }^{67}$ Daily Telegraph, 30 August 2013.

${ }^{68}$ The Guardian, 20 April 1999.

${ }^{69}$ The Times, 13 November 1998.
} 
sense, death and bereavement, comparable to the events of 1914-1918 are all that awaits the British Army in their operation in Afghanistan. ${ }^{70}$

The direct associations made between current concerns and the First World War can also be observed in the reuse and manipulation of images from the conflict. Political cartoonists frequently harness the visual history of the war for use in their work, including photographs, artwork and propaganda. This draws past and present together to enable a critical commentary on current political concerns. This is most notable in the reuse of the Alfred Leete image of Lord Kitchener of $1914 .{ }^{71}$ Political cartoonists refer to this image to effect issues of power, pride, incompetency and duplicity on a range of issues beyond the military realm. For example, Peter Schrank reworked the original drawing by Leete for The Independent newspaper in October 2002 to comment upon the increasing reliance of unqualified classroom assistants to take upon teaching roles as a cost-cutting measure. Education Secretary Estelle Morris is depicted in Kitchener's role with the slogan, 'Pupils "Need You” Join Our Mum's Army! God Save The Treasury'. ${ }^{72}$ The same use of the image is made by the cartoonist Paul Thomas in the Daily Express of June 2006 in response to the Metropolitan Police Commissioner's policies of public policing. The Commissioner takes Kitchener's place and proclaims 'Your country needs you to do our job'. ${ }^{73}$ Leete's poster was also reused by Paul Thomas before in the Daily Express in July 2004 to critique the Government's policies of redundancies within the British Army, with the Defence Secretary Geoff Hoon now featured on the poster stating 'Your country no longer needs you'. ${ }^{74}$ During the 'War on Terror', Leete's image was a powerful mode of discourse for political cartoonists seeking to expose the failings of the policies of the British Government. Peter Brookes in

\footnotetext{
${ }^{70}$ Daily Telegraph, 7 February 2008.

${ }^{71}$ Keith Surridge, 2001. More than a great poster: Lord Kitchener and the image of the military hero. Historical Research 74(185) (2001), 298-313.

${ }^{72}$ The Independent, 23 October 2002.

${ }^{73}$ Daily Express, 12 June 2006.

${ }^{74}$ Daily Express, 14 July 2004.
} 
December 2001 in The Times, Wally Fawkes in the Sunday Telegraph in February 2003 and Dave Brown in The Independent in January 2003 all critically place Prime Minister Tony Blair within Kitchener's place as an indictment of his foreign policies that has seen the deployment and deaths of British troops abroad. ${ }^{75}$

The same reuse of imagery from the First World War occurs with Bairnsfather's illustration of 'a better 'ole'. The image, demonstrating fortitude and humour in wartime, has been reinterpreted as demonstrating political malfeasance in the present on a range of issues. In June 1999, Nicholas Garland illustrated in the Daily Telegraph the response of Sinn Féin politicians in Northern Ireland over the retrieval of the bodies of those murdered during 'The Troubles' by placing Martin McGuinness and Gerry Adams together in a hole dug by an inept public relations exercise as they advised each other to locate 'a better 'ole'. ${ }^{76}$ Demonstrating the adaptability of the image and its use across a number of concerns, Steve Bell, mocked the Vietnam War record of President G.W. Bush in The Guardian in February 2004 through Bairnsfather's image. Bell, placed the President and his father, President G. Bush, in front of a television screen on bean bags as they watched the war in Vietnam unfold with the President stating to his father to find 'a better 'ole'. ${ }^{77}$ Morten Morland, in his illustration for The Times in March 2010, places the then Prime Minister Gordon Brown into the image to respond to accusations that troops in Iraq and Afghanistan were not properly equipped. Standing beside the corpse of a dead soldier, the Prime Minister reassures the nation that 'Well, no request for a better 'ole was turned down!'78 By making the past war present through these images, political cartoonists do not merely reiterate clichés about the conflict fought at the outset of the twentieth century. They utilise this history in order to comprehend contemporary events. Such evocations of the past are not simply accepted by their readership, it constitutes a

\footnotetext{
${ }^{75}$ The Times, 21 December 2001; Sunday Telegraph, 16 February 2003; The Independent, 22 January 2003.

${ }^{76}$ Daily Telegraph, 2 June 1999.

${ }^{77}$ The Guardian, 12 February 2004.

${ }^{78}$ The Times, 8 March 2010.
} 
discourse through which politics, power and identity are constructed and maintained. Political cartoons are not the product of popular memory nor do they structure that remembrance, rather they demonstrate how the past is mobilised in the present for current issues.

\section{Conclusions}

Political cartoons and comic art in Britain have served as a means of mobilising opinion, values, and ideals from the outbreak of the First World War to its centenary. Indeed, in the years after the cessation of hostilities cartoonists working across a number of national newspapers have frequently returned to the subject to the extent that it can be classified as a regular motif of political cartoons within Britain. However, the medium has been neglected in assessments of how the remembrance of the conflict has been structured and performed. In recent years the way in which the First World War has been remembered in Britain has been the subject of criticism. Historians have highlighted that the 'popular memory' of the conflict is the result of a clichéd image of the war, reducible to 'rats, gas, mud and blood'. In this assessment, 'history', in the form of a war that was supported by the majority within society, fought with a high level of morale by the solders and brought to a successful conclusion by the military and political leaders, has been supplanted by 'memory', which takes the form of pity, loss, trauma and futility. The cause for such perceptions have been examined as the result of media representations of the war which have concentrated on a narrow, limited assessment of the conflict and which have been more easily consumed by audiences. However, such analyses do not consider the function of the popular memory within British society. The remembrance of the conflict of 1914-1918 serves a number of purposes and constitutes a means of expressing identity and place within contemporary Britain. Through an examination of the function of remembrance, scholars can assess the complex way in which 
discourses regarding the First World War structure and respond to political agendas and power relations across society.

Political cartoons are a highly valuable source of evidence for this assessment as they function as both a means of reinforcing norms and stability but also constitute a locale of resistance and dissent. Their neglect by scholars in assessing how the war has been represented through a variety of media constitutes a significant oversight as they reveal the function of remembrance within Britain. By using a critical discourse analysis, the political cartoons from the 1920s onwards are observed to be structured by common elements that enable them to be mobilised to frame current concerns. Depictions of war-torn battlefields, dangerous trenches or suffering soldiers serve as way in which current concerns and issues can be framed and comprehended. Frequently, this operates as a means by which the policies of government or the actions of politicians can be critiqued. The reuse of images and details from the conflict to illustrate current debates, therefore, demonstrates that the popular memory of the conflict is not born out of a simplistic acceptance of media images. Rather, it operates as a discourse within society which can expose failings, highlight abuses of power and condemn lapses in responsibility. Political cartoons that reference the First World War to explain events and issues beyond the confines of 1914-1918 do not simply perpetuate the popular memory of the war, they demonstrate how the conflict functions within British society and how cartoons serve as frameworks that can be utilised to reveal concerns and mobilise opinion. In that sense, despite the passing of over a century since the war, British political cartoonists will continue to return to 'the trenches'. 